\title{
Salmonella enterica ssp. arizonae infection in a 43-year-old Italian man with hypoglobulinemia: a case report and review of the literature
}

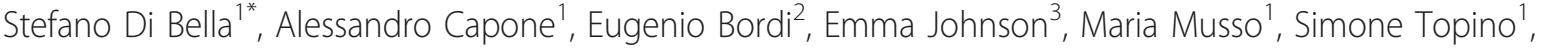 \\ Pasquale Noto ${ }^{1}$ and Nicola Petrosillo ${ }^{1}$
}

\begin{abstract}
Introduction: Salmonella enterica ssp. arizonae is an uncommon human pathogen with serious infections reported in immunocompromised hosts. In Europe, only a few cases have been described. Patients with this infection usually have a history of contact with reptiles or travel abroad. We present a case report of infection in a patient with hypoglobulinemia and a literature review.

Case presentation: We describe the case of a 43-year-old Caucasian Italian man with hypoglobulinemia who presented to our hospital with sepsis and diarrhea. A stool culture yielded S. enterica ssp. arizonae. Our patient was treated with oral ciprofloxacin and made a full recovery. We also present a review of the cases of $\mathrm{S}$. enterica ssp. arizonae infections previously reported in Europe.

Conclusions: The majority of infections from S. enterica ssp. arizonae occur in patients who are immunocompromised. Data from the literature suggests that it may be difficult to eradicate the bacteria and thus, prolonged antibiotic courses are often used. It would be advisable for clinicians to investigate for pre-existing immune dysfunction if S. enterica ssp. arizonae is isolated. In Italy, although there have only been a few cases, the likely route of transmission remains unclear and requires further surveillance.
\end{abstract}

\section{Introduction}

Salmonella enterica ssp. arizonae is an uncommon human pathogen with serious human infections reported in hosts with impaired immune function. S. enterica ssp. arizonae infections have been well described in patients resident within the southwestern part of the US and in Mexico, whereas in Europe only a few cases have been reported. Patients with this infection usually have a history of contact with reptiles or travel abroad.

We present a case report of S. enterica ssp. arizonae infection in an adult patient with hypoglobulinemia and literature review of previous cases.

\section{Case presentation}

A 43-year-old Caucasian Italian man was admitted to our hospital presenting with fever, mucoid diarrhea and

\footnotetext{
* Correspondence: stefano932@gmail.com

'Second Infectious Diseases Division, National Institute for Infectious

Diseases, 'Lazzaro Spallanzani', Via Portuense, 29200149 , Rome, Italy

Full list of author information is available at the end of the article
}

abdominal cramps for the past 20 days. Associated symptoms included malaise and a $5 \mathrm{~kg}$ weight loss during this time. During the previous week he had taken paromomycin along with bacitracin and neomycin, with no clinical improvement.

He had been diagnosed with Hodgkin's disease 15 years previously, which was treated with chemotherapy and autologous bone marrow transplant. Three years ago he had experienced a relapse, which was treated with chemotherapy alone. Since then a residual panhypoglobulinemia had been recorded in our patient. He reported extensive travel to many countries around the world, but not during the last year. He was taking no medications and had no known drug allergies.

On admission he was unwell with fever $\left(38.5^{\circ} \mathrm{C}\right)$, hypotension $(90 / 60 \mathrm{mmHg}$ ) and signs of dehydration. His lungs were clear and cardiac evaluation was normal. He had abdominal tenderness but there was no organomegaly or masses on palpation. Chest radiograph,

\section{C) Biomed Central}


abdomen ultrasound and electrocardiogram results showed no abnormalities.

Blood cultures and stool cultures for Salmonella spp., Shigella spp, Campylobacter spp. and Yersinia spp. were sent to our laboratory. Fecal examinations revealed presence of fecal occult blood $(+++)$ and many leukocytes. Investigation for parasites and immunofluorescence for Giardia were negative. Biochemical analysis showed a normal white blood cell count $\left(4.3 \times 10^{3}\right.$ cells $\left./ \mathrm{mm}^{3}\right)$ but revealed very low levels of immunoglobulins: IgG $91 \mathrm{mg} /$ $\mathrm{dL}$ (range 800 to $1500 \mathrm{mg} / \mathrm{dL}$ ), IgA $4 \mathrm{mg} / \mathrm{dL}$ (range 90 to $450 \mathrm{mg} / \mathrm{dL}$ ) and IgM $1 \mathrm{mg} / \mathrm{dL}$ (range 60 to $350 \mathrm{mg} / \mathrm{dL}$ ). Transaminases, renal function and coagulation studies were normal. Inflammatory markers, including erythrocyte sedimentation rate and $\mathrm{C}$ reactive protein, were elevated. Blood culture results were negative and supportive therapy with intravenous fluids was started.

On the sixth day of admission, Gram-negative bacilli were isolated from stool cultures and the bioMérieux VITEK $^{\circledR} 2$ system was used to identify the $S$. enterica ssp. arizonae. Phenotyping of this Salmonella isolate was also performed by the API 20E system (bioMèrieux), confirming the subspecies.

The bacterium was susceptible to all the tested antibiotics (Table 1). Therefore antimicrobial therapy with oral ciprofloxacin (500 mg every 12 hours) was started, after which there was a rapid improvement in our patient's clinical condition, with complete defervescence and cessation of the diarrhea.

Due to the severe humoral immunodeficiency in our patient, ciprofloxacin was continued for a total of 28 days. Our rationale was the evidence in the literature that suggests possible later relapse if short antibiotic treatment courses are used [1]. He continued to improve and fecal cultures taken one week and two weeks after the discontinuation of antibiotic therapy were negative.

\section{Discussion}

Salmonella spp. are Gram-negative bacilli and members of the Enterobacteriaceae family. They are documented to be pathogens that cause a spectrum of diseases in humans and animals, including domesticated and wild mammals, reptiles, birds, and insects. Salmonella spp. infections are caused by consumption of contaminated food, person-to-person transmission, waterborne transmission and numerous environmental and animal exposures.

S. enterica ssp. arizonae is one of the less common subspecies of Salmonella. Like many non-typhoidal salmonellae, it is mostly found in animal species (commonly reptiles) and only occasionally infects humans. Snakes appear to be important carriers of this bacterium, with as many as $78.8 \%$ harboring the organism [2].

S. enterica ssp. arizonae can be difficult to identify due to their distinguishing biochemical features, which include the ability to utilize malonate, liquefy gelatin and the inability to grow in the presence of $\mathrm{KCN}$ (potassium cyanide). Isolation of $S$. enterica ssp. arizonae from the stools is difficult as some strains ferment lactose within 48 hours (approximately 15\%) and they may be routinely discarded as non-pathogens. However the presence of hydrogen sulfide is an important diagnostic clue during routine screening [3].

This Salmonella isolate did not ferment lactose within the first 24 hours so it was further investigated as a

Table 1 Tested antibiotics

\begin{tabular}{|c|c|c|}
\hline Antibiotic & Minimal inhibitory concentration, $\mu \mathrm{g} / \mathrm{mL}$ & Sensitivity \\
\hline Amikacin & $\leq 2$ & $S$ \\
\hline Amoxicillin/Clavulanate & $\leq 2$ & $S$ \\
\hline Ampicillin & $\leq 2$ & $\mathrm{~S}$ \\
\hline Cefepime & $\leq 1$ & $S$ \\
\hline Cefotaxime & $\leq 1$ & $\mathrm{~S}$ \\
\hline Ceftazidime & $\leq 1$ & $S$ \\
\hline Ciprofloxacin & $\leq 0.25$ & $\mathrm{~S}$ \\
\hline Ertapenem & $\leq 0.5$ & $\mathrm{~S}$ \\
\hline Gentamicin & $\leq 1$ & $S$ \\
\hline Imipenem & $\leq 1$ & $S$ \\
\hline Levofloxacin & $\leq 0.12$ & $\mathrm{~S}$ \\
\hline Meropenem & $\leq 0.25$ & $S$ \\
\hline Piperacillin/Tazobactam & $\leq 4$ & $\mathrm{~S}$ \\
\hline Tobramycin & $\leq 1$ & $\mathrm{~S}$ \\
\hline Trimethoprim/Sulfamethoxazole & $\leq 20$ & $\mathrm{~s}$ \\
\hline
\end{tabular}

$\mathrm{S}=$ sensitive; $\mathrm{I}$ = intermediate; $\mathrm{R}$ = resistant. 
Salmonella species. However, it is prudent, particularly in patients who are immunosuppressed presenting with fever and diarrhea, that coliforms of potential significance are identified where possible. The use of commercial identification kits or automated systems such as VITEK 2, may be necessary.

Since it is becoming increasingly common to keep reptiles as pets, it appears that the incidence of infection with S. enterica ssp. arizonae is increasing [1]. The organism is part of the normal reptile intestinal flora but can cause disease in monotremes, turkeys, chickens, goats, and humans [4]. S. enterica ssp. arizonae enteritis or systemic infections have been well described in patients resident in the southern states of the USA [5], whereas in Europe it is much rarer, with only a few cases reported in the literature [4,6-17]. Many cases reported in the US-Mexican border region were related to the use of rattlesnake products (capsules composed of a powder of dried, crushed snake) as an alternative form of medical treatment [5]. This is a common practice in Mexican folk remedies. Rattlesnake capsules are easily obtained in Mexico without a prescription [5].

Most cases of invasive S. enterica ssp. arizonae infection have been either in younger patients or those with underlying diseases including collagen vascular diseases, malignancy, organ transplantation and HIV infection [18]. This case highlights, once again, the association between the immunocompromised host and increased susceptibility to $S$. enterica ssp. arizonae.

We performed a review of the literature available using the PubMed database, searching for cases of S. enterica ssp. arizonae infections reported in Europe. We found 16 articles from 1992 to 2010. Features of the reported cases are presented in Table 2 [4,6-17].

In the cases reported in Europe, S. enterica ssp. arizonae infections are frequently associated with reptile exposure and underlying diseases, similar to those found in North-Central America. However, in Italy only three cases of this infection have been reported but none described any contact with reptiles.

Table 2 European cases of Salmonella enterica ssp. arizonae infection

\begin{tabular}{|c|c|c|c|c|c|}
\hline $\begin{array}{l}\text { Reference (first } \\
\text { author/year) }\end{array}$ & Country & $\begin{array}{l}\text { Type of infection } \\
\text { (no. of cases) }\end{array}$ & Possible exposure & Specimens & Underlying conditions \\
\hline Aiken, 2010 [5] & UK & Unknown (3) & $\begin{array}{l}\text { Reptiles (two patients), not } \\
\text { reported (one patient) }\end{array}$ & Not reported & Not reported \\
\hline $\begin{array}{l}\text { Schneider, } 2009 \\
\text { [6] }\end{array}$ & France & Septic arthritis (1) & Snake & Synovial fluid & Young age \\
\hline \multirow[t]{4}{*}{ Bertrand, 2008 [7] } & Belgium & Not reported (3) & Snakes (three patients) & Not reported & $\begin{array}{l}\text { Young age (two patients), } \\
\text { dialytic treatment (one } \\
\text { patient) }\end{array}$ \\
\hline & Netherlands & Not reported (16) & Reptiles (most patients) & Not reported & Not reported \\
\hline & Germany & Not reported (2) & Snakes (two patients) & Not reported & $\begin{array}{l}\text { Young age (one patient), } \\
\text { unknown (one patient) }\end{array}$ \\
\hline & Ireland & Not reported (1) & Snake & Not reported & Young age \\
\hline Starakis, 2007 [8] & Greece & Endocarditis (1) & $\begin{array}{l}\text { Vegetables contaminated with } \\
\text { turtles feces }\end{array}$ & Blood & $\begin{array}{l}\text { Sickle cell disease, secondary } \\
\text { hemochromatosis }\end{array}$ \\
\hline Ozdemir, 2006 [9] & Turkey & Sepsis (1) & Unknown & Blood & AIDS \\
\hline Foster, 2005 [10] & UK & Gastroenteritis (1) & Reptiles & Stools & Young age \\
\hline Salavert, 2002 [11] & Spain & $\begin{array}{l}\text { Abdominal abscess } \\
\text { (1) }\end{array}$ & Veterinarian patient & $\begin{array}{l}\text { Pericardial effusion, } \\
\text { pericardial biopsy }\end{array}$ & Obesity \\
\hline Catani, 2002 [12] & Italy & Pericarditis (1) & Travels & Pus & $\begin{array}{l}\text { Chronic renal failure on } \\
\text { dialytic treatment }\end{array}$ \\
\hline $\begin{array}{l}\text { Carfagna, 1998* } \\
\text { [13]; Galiè, 1997* } \\
\text { [14] }\end{array}$ & Italy & Severe sepsis (1) & Travels & Blood & $\begin{array}{l}\text { Idiopathic CD4+ } \\
\text { lymphocytopenia }\end{array}$ \\
\hline $\begin{array}{l}\text { Carfagna, } 1998 \\
\text { [13] }\end{array}$ & Italy & Septic shock (1) & Travels & $\begin{array}{l}\text { Brain and lungs, } \\
\text { autoptic specimens }\end{array}$ & $\begin{array}{l}\text { Chronic lymphatic leukemia } \\
\text { on cytostatic treatment }\end{array}$ \\
\hline Sanyal, 1997 [15] & UK & Gastroenteritis (1) & Snakes & Stools & $\begin{array}{l}\text { Young age, Netherton's } \\
\text { syndrome }\end{array}$ \\
\hline Buck, 1997 [16] & UK & Gastroenteritis (1) & Reptiles (snake) & Stools & Young age \\
\hline Hall, 1992 [17] & $\begin{array}{l}\text { UK ( } 66 \text { cases } \\
\text { from } 1966 \text { to } \\
1990)\end{array}$ & $\begin{array}{l}\text { Enteritis (55), } \\
\text { symptomless (6), } \\
\text { unknown (3) }\end{array}$ & $\begin{array}{l}\text { Travels } 23 \text { patients (35\%), } \\
\text { terrapins two patients, snakes } 11 \\
\text { patients }\end{array}$ & $\begin{array}{l}\text { Blood (two } \\
\text { patients), stools (66 } \\
\text { patients) }\end{array}$ & $\begin{array}{l}49 \% \text { of infections occurred } \\
\text { in babies and young } \\
\text { children }\end{array}$ \\
\hline
\end{tabular}


This is the fourth case reported in Italy and, indeed, our patient also had no history of contact with reptiles. In a study conducted in UK from 1966 to 1990, 12 isolations of S. enterica ssp. arizonae were derived from human foods and, among these, seven isolates were from imported Italian pasta [17]. A recent study detected S. enterica ssp. arizonae from Pecorino Abruzzese, a traditional cheese produced in Central Italy [19]. Therefore, it is possible that our patient contracted the bacteria from the ingestion of contaminated food.

S. enterica ssp. arizonae has been found to be susceptible to commonly prescribed antibiotics in several of the case reports, as was the strain isolated from our patient.

\section{Conclusions}

The isolation of S. enterica ssp. arizonae is commonly associated with a deficit of the immune status, as in the case of our patient. Indeed, the great majority of infections from S. enterica ssp. arizonae occur in patients who present with underlying medical conditions.

Data from the literature suggest that, for patients who are immunocompromised, it may be more difficult to eradicate the bacteria and thus prolonged antibiotic courses ( $>14$ days) are often advisable. The absence of recurrence in our patient suggests that 28 days was an appropriate course length.

In conclusion, although infection from S. enterica ssp. arizonae is rare, it is most prevalent in patients of a younger age or those with underlying diseases. Therefore, it would be advisable for clinicians to investigate for preexisting immune dysfunction if S. enterica ssp. arizonae is isolated. Finally, in Italy, although there have only been a few cases, the likely route of transmission remains unclear and requires further surveillance.

\section{Consent}

Written informed consent was obtained from the patient for publication of this case report and any accompanying images. A copy of the written consent is available for review by the Editor-in-Chief of this journal.

\footnotetext{
Acknowledgements

This work was supported by a grant from Ricerca Corrente Istituti di Ricovero e Cura a Carattere Scientifico (IRCCS).

\begin{abstract}
Author details
'Second Infectious Diseases Division, National Institute for Infectious Diseases, 'Lazzaro Spallanzani', Via Portuense, 292 00149, Rome, Italy. ${ }^{2}$ Microbiology Laboratory, National Institute for Infectious Diseases, 'Lazzaro Spallanzani', Via Portuense, 292 00149, Rome, Italy. ${ }^{3}$ Clinical Microbiology
\end{abstract} Registrar, Sheffield Teaching Hospitals Trust, Sheffield, UK.
}

\section{Authors' contributions}

SD and MM monitored our patient during hospitalization and analyzed data from the literature. EB isolated and identified the bacterium. AC, PN and ST performed the follow-up of our patient after discharge. EJ was the major contributor in writing the manuscript. NP reviewed the manuscript. All authors have read and approved the final manuscript.

\section{Competing interests}

NP has received industry honoraria for lecturing from Wyeth, GSK, Pfizer, MSD, Novartis, Sanofi Aventis, Janssen Cilag, Carefusion, Astellas, Gilead. All other authors report no conflicts.

Received: 28 December 2010 Accepted: 22 July 2011

Published: 22 July 2011

\section{References}

1. Bhatt BD, Zuckerman MJ, Foland JA, Polly SM, Marwah RK: Disseminated Salmonella arizona infection associated with rattlesnake meat ingestion. Am J Gastroenterol 1989, 84:433-435.

2. Habermalz D, Pietzsch O: Identification of arizona bacteria. A contribution to the problem of salmonella infections among reptiles and amphibians in zoological gardens. Zentralbl Bakteriol Orig A 1973, 225:323-42.

3. Winn W, Allen SD, Allen S, Janda W, Koneman EW, Schreckenberger PC, Procop GW, Woods GL: Koneman's Color Atlas and Textbook of Diagnostic Microbiology. 6 edition. Baltimore, MD: Lippincott Williams \& Wilkins; 2006.

4. Aiken AM, Lane C, Adak GK: Risk of Salmonella infection with exposure to reptiles in England, 2004-2007. Euro Surveill 2010, 15:19581.

5. Casner PR, Zuckerman MJ: Salmonella arizonae in patients with AIDS along the U.S.-Mexican border. N Engl J Med 1990, 323:198-199.

6. Schneider L, Ehlinger M, Stanchina C, Giacomelli MC, Gicquel P, Karger C, Clavert JM: Salmonella enterica subsp. arizonae bone and joints sepsis. A case report and literature review. Orthop Traumatol Surg Res 2009, 95:237-242.

7. Editorial team, Bertrand S, Rimhanen-Finne R, Weill FX, Rabsch W, Thornton L, Perevoscikovs J, van Pelt W, Heck M: Salmonella infections associated with reptiles: the current situation in Europe. Euro Surveill 2008, 13:18902.

8. Starakis I, Siagris D, Karatza C, Solomou H, Bassaris H: Endocarditis due to Salmonella enterica subsp. arizonae in a patient with sickle cell disease: a case report and review of the literature. Cardiovasc Hematol Disord Drug Targets 2007, 7:199-204.

9. Ozdemir D, Sahin I, Sencan I: Salmonella arizonae bacteraemia in a Turkish patient with AIDS but no history of contact with reptiles. Scand J Infect Dis 2006, 38:237-238.

10. Foster $\mathrm{N}$, Kerr $\mathrm{K}$ : The snake in the grass-Salmonella arizonae gastroenteritis in a reptile handler. Acta Paediatr 2005, 94:1165-1166.

11. Salavert M, Navarro V, Roig P: Purulent pericarditis due to Salmonella enterica subsp. arizonae. Enferm Infecc Microbiol Clin 2002, 20:47-49.

12. Catani M, De Milito R, Intrieri F, Fidente D, Venditti M, Manili G, Siani A, Capitano S: Systemic Salmonella arizona infection: description of a rare surgical case. Minerva Chir 2004, 59:75-78.

13. Carfagna P, Brandimarte C, Bianco G, Galiè M, Paris A, Venditti M: Systemic Salmonella arizonae infections in patients with a deficiency of cellmediated immunity. A report of 2 cases and a review of the literature. Recenti Prog Med 1998, 89:632-636.

14. Galiè M, Cassone M, Ausiello C, Serra P: Idiopathic CD4+ T-lymphocyte deficiency: the clinical evolution of a case. Ann Ital Med Int 1997, 12:233-237.

15. Sanyal D, Douglas T, Roberts R: Salmonella infection acquired from reptilian pets. Arch Dis Child 1997, 77:345-346.

16. Buck JJ, Nicholls SW: Salmonella arizona enterocolitis acquired by an infant from a pet snake. J Pediatr Gastroenterol Nutr 1997, 25:248-249.

17. Hall ML, Rowe B: Salmonella arizonae in the United Kingdom from 1966 to 1990. Epidemiol Infect 1992, 108:59-65.

18. Hoag JB, Sessler CN: A comprehensive review of disseminated Salmonella arizona infection with an illustrative case presentation. South Med J 2005, 98:1123-1129.

19. Chaves-López C, De Angelis M, Martuscelli M, Serio A, Paparella A, Suzzi G. Characterization of the Enterobacteriaceae isolated from an artisanal Italian ewe's cheese (Pecorino Abruzzese). J Appl Microbiol 2006 101:353-360

doi:10.1186/1752-1947-5-323

Cite this article as: Di Bella et al.: Salmonella enterica ssp. arizonae infection in a 43-year-old Italian man with hypoglobulinemia: a case report and review of the literature. Journal of Medical Case Reports 2011 5:323. 